\title{
The Hydrologic Performance of a Permeable Pavement
}

\author{
JE BdPRAFRankin ${ }^{2}$
}

Faculty of Engineering, University of Technology Sydney, Sydney, Australia

Formerly Postgraduate Student, School of Civil and Environmental

Engineering, The University of New South Wales, Sydney, Australia 


\begin{abstract}
Urban stormwater runoff is a transport medium for many contaminants from anthropogenic sources. There are many alternative management strategies available to treat these contaminants. One of the technologies suggested for this purpose is the use of permeable pavements to minimise the quantity of surface runoff generated by impervious surfaces within an urban catchment. Reported herein are the results of a monitoring program undertaken to assess the effectiveness of permeable road surface for reducing the quantity and quality of stormwater runoff. It was found that the catchment, where the permeable road surface was installed, had the effective imperviousness reduced from $45 \%$ prior to reconstruction of the road surface to less than $5 \%$ after reconstruction of the road. Furthermore, it was found that the generation of surface runoff from the permeable road surface required a rainfall intensity in excess of $20 \mathrm{~mm} / \mathrm{h}$. Finally, the quality of the surface runoff was found to be at the lower levels of runoff from road surfaces while no increase in stormwater contaminants within the groundwater system was monitored.
\end{abstract}

\title{
Keywords DRAFT
}

Road, Urban, Runoff, Stormwater, Quality 


\section{INTRODUCTION}

Contamination borne by stormwater originates from a variety of sources inclusive of the rainfall itself, and the pervious and impervious surfaces within the catchment. Many of the frequent storm events, however, result in the generation of surface runoff only from the impervious surfaces within the catchment. Due to this importance of runoff from impervious surfaces, a number of studies have investigated the availability or transport of pollutant constituents from impervious surfaces. Examples of these studies are those by Sartor and Boyd (1972), Shaheen (1975), Ellis and Revitt (1982) and Ball et al. (1998) who all investigated the availability of pollutant constituents on road surfaces. In a similar manner, Barrett et al. (1993), Batley et al. (1994), Sansalone (1996) and Brockbank et al. (1998) have investigated the chemical composition of stormwater runoff from road surfaces.

An indication of the range of contaminants typically found in runoff from road surfaces, and some likely sources of these contaminants is presented in Table 1. As can be seen from this table, there is a wide variety of potential pollutants in urban stormwater arising from traffic related sources.

\section{Insert Table 1}

\section{DRAFT}

A major consideration in the assessment of this contamination is the form in which the contaminants are present. It is important, for example, to know whether the contaminant is dissolved in the water, ie a soluble contaminant, adsorbed to particulate matter, ie a particulate contaminant, or in an organic form. If contaminants are associated with particulates the size distribution of the particulate matter plays an important role in the settling and transport characteristics of that pollutant. Larger particles will settle more rapidly while fine particulates may remain suspended in the water column indefinitely.

Many contaminants have been shown to exhibit a strong association with particulates in stormwater runoff. Additionally, pollutant constituents have been shown by, for example, Bradford (1977) and Sartor and Boyd (1972) to be more likely to be sorbed to the finer particulates than to the larger particulates in urban stormwater. Ball and Abustan (1995) report that up to $85 \%$ of phosphorous and $70-80 \%$ of the nitrogen can be isolated as particulate matter. Ball and Abustan (1995) also showed that on average about $80 \%$ of phosphorous was in particulate form during the peak of the storm events that they monitored. Environment Australia (2002) presents similar results. PAHs (polycyclic aromatic hydrocarbons) and metals also tend to be associated with particulate matter. Baek et al. (1991) found PAHs to frequently be attached to particles between 0.1 and 3.0 $\mu \mathrm{m}$ and Walker and Hurl (2002) show that metals tend to be associated with particulate matter with a preference being shown for the finer 
particles. Similar results are reported also by Ball (2000).

There have been many alternative approaches suggested for the management of runoff from road surfaces and the associated contamination. One such approach is the application of Water Sensitive Urban Design (WSUD) principles. Environment Australia (2002) describes WSUD as

an approach that incorporates water management systems into buildings, urban transport routes, and public open spaces. It is a concept that sees water as a resource rather than a waste product and that addresses stormwater problems at source rather than finding "end-of-pipe" solutions. It involves focussing on water resources at an early stage in urban development to ensure that the development is suitable for the rainfall-runoff characteristics of that particular area. The concept incorporates both water quality and water quantity aspects of stormwater management with the aim of minimising the impacts of human activities.

Permeable pavements are an example of a WSUD component. They provide a special type of pavement surface that allows water to infiltrate through the surface as an alternative to the traditional impermeable surfaces. The intention of permeable pavements is to allow the catchment surface to respond in a more natural manner and thereby to return somethentility to an urbanised catchment. Their use, therefore, is expected to result in a decrease in the volume of runoff and hence a decrease in the pollutant mass transported to local waterways in comparison with a conventional impermeable road surface.

Instead of running off the pavement surfaces, stormwater passes through the pavement into the subgrade material below where it is stored temporarily before it is either collected and discharged into a formal stormwater drainage system or simply left to infiltrate through the soil beneath the road structure. Standard road bases are designed to remove any water as quickly as possible to prevent damage occurring to the road surfaces. For this reason, the subgrade for permeable pavements needs to be specifically designed so that the desired temporary storage ability can be achieved without damage to the road pavement (Dirkes et al., 2002).

The applicability of permeable pavements generally is seen to depend on underlying soil characteristics and land gradients as well as the type of use that the pavement is expected to receive. Roads with low traffic volumes, car parks, driveways, pedestrian paths, and the shoulders of airport taxiways are all seen as land uses that are compatible with permeable pavements. Gentle slopes and permeable soils are also required (Bettess 1996, NSW EPA 1997, US EPA 1999). 
Various studies have found that use of permeable pavements is effective in reducing the volume of stormwater runoff so long as the pavement is carefully designed, carefully located and is regularly maintained to reduce clogging of the pore spaces (Hunt et al., 2002, Pratt et al., 1995, Rushton, 2001). Runoff coefficients, which can be defined as the proportion of the rainfall that is converted into runoff, were used in the assessment of the effectiveness of the pavements in these studies. It was found that the average runoff coefficient associated with an asphalt surface in this parking lot was 0.58 while that of a pervious pavement surface was only 0.10 .

Hunt et al. (2002), when studying a permeable parking lot, found that the effectiveness of porous pavements is reduced as the amount of rainfall in an event increases. For their study site they found that the average runoff coefficient ranged from 0.20 to 0.50 , where higher runoff coefficients were associated with events which resulted in a greater depth of rainfall. However, Hunt et al. (2002) also found that runoff generation was not based on the total volume of rain fallen but rather upon the intensity. Generally, it was only very intense storm events that produced runoff at the site they studied.

Rushton (2001) compared different pavement surfaces in a parking lot. This study found the average runoff coefficient associated with an asphalt surface in this parking lot to be 0.58 while that of a pervious pavement surface was found to be 0.10 . It shquld be noted that Rushton (2001) notes drought conditions were experienced during the study, while Huttet $(2502)$ report that a hurricane occurred during their study.

Reported herein are the results of a monitoring program undertaken to assess the effectiveness of permeable road surface for reducing the quantity and quality of stormwater runoff. It was found that the catchment, where the permeable road surface was installed, had the effective imperviousness reduced from $45 \%$ prior to reconstruction of the road surface to less than $5 \%$ after reconstruction of the road. Furthermore, it was found that the generation of surface runoff from the permeable road surface required a rainfall intensity in excess of $20 \mathrm{~mm} / \mathrm{h}$. Finally, the quality of the surface runoff was found to be at the lower levels of runoff from road surfaces while no increase in stormwater contaminants within the groundwater system was monitored.

\section{CATCHMENT CHARACTERISTICS}

The permeable pavers monitored during this project were installed in the northern end of Smith Street which is located within the Pine Street catchment. As shown in Figure 1, the Pine Street catchment is located in the suburb of Manly approximately $8 \mathrm{~km}$ from the Sydney CBD. The catchment extends from 
Augusta Road in the south to Quinton Road in the west to Alexander Street in the north to North Steyne Beach in the east. Flows from the stormwater system draining this catchment impact on North Steyne Beach (a northern continuation of Manly Beach) and therefore stormwater drainage issues within the catchment and its receiving waters are a high priority to both the local community and visitors to the region.

In general, the western portions of the catchment at 52m AHD are higher than the eastern portions which abut North Steyne Beach. Slopes in the western portions of the catchment are higher also than those in the eastern portions where minimal surface grades occur from Smith to the ocean in the east. Land use within the Pine Street is predominantly residential although there are small pockets of commercial development along North Steyne and Pittwater Road. Finally, the underlying soil strata varies across the catchment with the eastern portions of the catchment, where the permeable pavements were constructed, overlaying sand. On the other hand, the western portions of the catchment and those portions of the catchment with a higher elevation overlay rock. As a result, there is a higher potential for infiltration of rainfall in the eastern portion of the catchment than in the western portion of the catchment.

\section{Insert Figure 1}

Smith Street site is a residential street with a area comprising the northern end of Smith Street (where the permeable pavement has been placed) and the houses immediately on either side of the street. Stormwater on Smith Street originates from rain falling directly onto the road surface, as well as runoff from roofs, driveways and other land surfaces of the residential properties in the street. Prior to the construction of the permeable pavement, this stormwater was collected through conventional stormwater drainage network inlets and drained to the ocean through a stormwater outfall on North Steyne beach.

\section{Insert Figure 2}

A gauging station was set up at the Smith Street site, just to the north of Pacific Lane, on the western side of the road. As shown in Figure 2, the catchment area monitored by the gauging station is less than the entire Smith Street subcatchment area. The total subcatchment area is approximately $0.65 \mathrm{ha}$, while the gauging station only monitors an area of about 0.15 ha in the north western corner of the catchment.

At the gauging station, the following equipment were installed

- Rain Gauge - a $0.2 \mathrm{~mm}$ pluviometer; 
- Water Level Measurements - a water surface seeker was used to measure the water level in the gutter. This device is able to measure the water level with an accuracy of $0.25 \mathrm{~mm}$ and hence measurements accurate to $1 \mathrm{~mm}$ were considered to be achievable;

- Automatic Grab Sampler - a Gamet automatic grab sampler was used to collect samples for subsequent analysis; and

- Data Logger - A Hydromace 2000 (HM2000) data logger was used to record rainfall and the water level in the gutter, and to trigger operation of the grab sampler.

\section{SMITH STREET PERMEABLE PAVEMENT}

As discussed earlier, various configurations can be adopted for a permeable pavement. These variations involve differences in the types and configuration of the pavers as well as differences in the disposal mechanism of the stormwater. Due to the presence of sandy soil on site that has an in-situ permeability of over $145 \mathrm{~mm} / \mathrm{hr}$, the Smith Street pavement was designed such that infiltrated water is simply discharged to the soil beneath (Rocla, 2002). The design was based on the use of Rocla Ecoloc pavers as the pavement surface. A geotechnical investigation undertaken for the site established that, beneath the original pavements of Smith Street, the subgrade comprised loose to medium dense sand overlain by silty sandy gravel or silty gravelly sand fi 0.4 and $1.0 \mathrm{~m}$. Furthermore, two in-situ constant head permeability tests of the subgrade ascertained that the coefficients of permeability were consistent with those expected for clean sands.

The Smith Street permeable pavement was designed to reduce the potential generation of stormwater runoff during frequent storm events. For events of this size, it can generally be expected that runoff will be generated only from the impervious areas in the catchment. Since the permeable pavement is expected to result in the road surface acting as a pervious area rather that an impervious area, generation of stormwater runoff is expected to be reduced during frequent storm events.

Rocla (2002) report that prior to the construction of the permeable pavement, the catchment area draining to Smith Street was estimated to be $45 \%$ effective impervious. As a result of installation of the pavement, Rocla (2002) claim that the effective imperviousness of the area has been reduced to around $20 \%$. Contaminant transport associated with stormwater runoff also was expected to reduce as a result of the permeable pavement. As previously discussed, the mass flux of a contaminant is directly related to the stormwater flow rate (Ball and Scarsbrick, 2001). Since less stormwater runoff is expected to be produced, the mass of contaminants being transported from the Smith Street catchment similarly is expected to reduce. 


\section{DATA ANALYSIS}

The analysis undertaken on the collected data at the Smith Street Gauging Station was event based. Therefore, to extract pertinent details from the collected data, it was necessary to determine the following

- Gauging Station Rating Curve - the rating curve developed for this Gauging Station is shown in Figure 3;

- Event Separation - Since the pavement structure is $460 \mathrm{~mm}$ deep, water infiltrating through the pavement will take about seven (7) hours to pass through. However, in relation to separating the events, it was not necessary that the pavement be completely empty rather it was thought necessary that a period of time be allowed to pass where no rainfall occurred so that some of the pavement storage capacity would be restored. A period of one hour was adopted as this limit.

- Volumetric RunoffCoefficients - The volumetric runoff coefficient was determined to assess whether the gauged catchment was responding to the rainfall as an effective impervious surface or as a pervious surface. The volumetric runoff coefficient represents the ratio of the volume (or depth) of rainfall that occurs during the supply period and the volume (or depth) of runoff that occurs (IEAust, 1987). The volume of rainfall was determined by assuming that the recorded depth of rainfall recorded for the event during both the sop the thent occurred evenly over the gauged catchment surface. The runoff volume then was calculated by determining the area under the runoff hydrograph.

- Event Mean Concentrations - Results from the laboratory analysis were provided as concentrations of the constituents in the collected sample. For comparison of the data between storm events and with typical runoff quality from road surfaces, event mean concentrations (EMC) were determined. The EMC is defined as the total pollutant mass $(\mathrm{M})$ divided by the volume of surface runoff $(\mathrm{V})$ (Huber, 1993) and, therefore, is a flow weighted average of the concentration within an event. The EMC can be expressed mathematically as

$$
E M C=\frac{M}{V}=\frac{\int C(t) Q(t) d t}{\int Q(t) d t}
$$

where C and Q represent the concentration and the runoff rate respectively. The water quality samples, however, were not collected as a continuous record. Hence the EMC for each event needed to be determined using discrete time intervals $(\Delta t)$. Therefore, the EMC was determined as 


$$
E M C=\frac{\sum_{i=1}^{n} C(t) Q(t) \Delta t}{\sum_{i=1}^{n} Q(t) \Delta t}
$$

Insert Figure 3

\section{$5 \quad$ RESULTS}

\subsection{Runoff Quantity}

Monitoring of the Smith Street site was undertaken between June 2002 and April 2003. The results from this monitoring have been analysed in terms of the quantity and the quality of runoff from the permeable pavement. Throughout the monitoring period a total of 22 rainfall events that resulted in runoff from the permeable pavement were recorded. Water quality samples were collected for 9 of these events. The smaller number of water quality samples with relation to runoff events is primarily due to the small quantity of runoff that was produced in many of the events, but also due to the occurrence of previous runoff events causing all of the bottles in the automatic sampler to be full.

\section{DRAFT}

In the analysis of the data obtained during the monitoring period, it should be noted that drought conditions were being experienced in the Sydney region. Shown in Figure 4 is a comparison of the rainfall recorded at Smith Street with average monthly rainfall for Sydney.

\section{Insert Figure 4}

Despite the drought conditions, a total of 22 events were recorded during the period of monitoring. These events ranged in magnitude from $2 \mathrm{~mm}$ to in excess of $50 \mathrm{~mm}$. Shown in Figure 5 are the maximum 5-minute rainfall intensities recorded during each of the 22 events. Also shown in this figure are the 1 year and 2 year ARI design rainfall intensities. It can be seen that although drought conditions were present throughout most of the 11 month monitoring period, event 21 (which occurred on the 12th April 2003) exceeded the 5 minute intensity associated with the design 2 year ARI. Other events were all below the design 1 year ARI. As a result, most of the runoff events recorded during the monitoring period can be expected to be a result of impervious area runoff only.

Insert Figure 5 
The perviousness of the gauged Smith Street catchment was assessed by comparing the volume of runoff from the catchment with the volume of rain that fell over the catchment during each event and during the supply period of the event. The volumetric runoff coefficient provides a measure for this comparison. The American Society of Civil Engineers (ASCE, 1969) has suggested values of runoff coefficients for various surfaces with these values ranging from $5 \%$ to $35 \%$ for pervious surfaces and from $70 \%$ to $90 \%$ for impervious surfaces.

While, the runoff coefficients were determined in terms of both a total runoff coefficient and a runoff coefficient representing the supply period of the event, the runoff coefficients during the supply period are discussed herein, as they represent the proportion of rain resulting in runoff after initial losses have occurred. The supply period runoff coefficients associated with the recorded events range from $0.04 \%$ to $7.33 \%$. At the $95 \%$ confidence level, it was determined that the supply period runoff coefficients would be between $2.15 \%$ and $3.85 \%$. These values indicate that very little runoff is occurring in comparison to the rainfall within each event. Furthermore, based on comparison with the values suggested by ASCE (1969), it appears that the gauged catchment is acting as a pervious area rather than an impervious one.

Shown in Figure 6 is a plot of the total recorded rainfallduring an event versus the runoff depth. By determining the slope of the line of best fit, an estmation of the effective imperviousness of the gauged catchment was obtained. For a completely impervious catchment, neglecting any rainfall losses, all of the rain that lands on the catchment surface will run off. This implies that a rainfall versus runoff plot would have a slope of 1 (rainfall = runoff). The slope of the Smith Street data rainfall - runoff plot was found to be approximately 0.05 as shown by the equation for the line of best fit through the data. This implies that the gauged catchment has an effective impervious of $5 \%$.

\section{Insert Figure 6}

The effective imperviousness of 5\% determined from Figure 6 is higher than the range given above for the $95 \%$ confidence interval for the mean of the supply period runoff coefficients. It was suspected that this result was due to pervious area runoff contributing to the gauged runoff for events where a greater depth of runoff was recorded. As mentioned above, most of the rainfall events recorded at Smith Street during the 11 month monitoring period were smaller than the 1 year ARI event, indicating that impervious area runoff dominates the runoff recorded on site.

Data shown in Figure 6 was replotted (see Figure 7) neglecting the 4 events which recorded larger 
quantities of runoff to assess the influence of these events on the effective imperviousness of the catchment. As shown in Figure 7, neglecting these events reduces the estimated effective imperviousness of the catchment to about $3 \%$, which is the same as the mean of the supply period runoff coefficients. Furthermore, as shown in Figure 7, the total rainfall has a reasonable correlation with the amount of runoff during an event $\left(\mathrm{R}^{2} \sim 0.86\right)$. This result confirms the hypothesis that pervious area runoff contributed to the catchment runoff for those events with a greater depth of was recorded.

\section{Insert Figure 7}

The rainfall-runoff relationship can be used also to gain an estimate of the initial loss as recorded for the gauged catchment. The location where the line of best fit crosses the rainfall axis represents this initial loss as no runoff occurs prior to this amount of rainfall occurring. As shown in Figure 7, analysis of the data recorded at Smith Street suggests that an initial loss of about $4 \mathrm{~mm}$ should be expected for this catchment.

The maximum 5 minute intensity for the storm events was plotted against the total runoff that occurred during the same 5 minute period to assess any correlation between the intensity of the rainfall and the depth of the runoff. This plot is shown in Figure ${ }^{8}$ Ascan be seen from this figure, a high correlation was found.

DRAFT

\section{Insert Figure 8}

This high correlation was expected as visual inspection of the individual event hydrographs indicates that runoff commences immediately after there is a significant increase in the rainfall intensity. Events 6 and 15 are particularly interesting in this respect. Both of these events have more than one peak in the runoff hydrograph and each peak corresponds to an increase in the intensity of the rainfall during the event.

The rainfall intensity that leads to runoff occurring provides an indication of the permeability of the permeable pavement. The pavement is capable of infiltrating $100 \%$ of the runoff only when the rainfall is below a given intensity. After this rate, the infiltration capacity of the permeable pavement is reached and water that is unable to be infiltrated will run over the pavement surface. As shown in Figure 8, the line of best fit crosses the maximum 5 minute intensity axis at about $20 \mathrm{~mm} / \mathrm{hr}$. This provides a rough indication of the rainfall intensity required to produce runoff as no runoff will occur unless this rainfall intensity is reached. 
An interesting point to note is that this is below the 5 minute intensity associated with the 1 year ARI, indicating that runoff is likely to occur frequently. However, as indicated by the low effective imperviousness estimated for the catchment and the low supply period runoff coefficients, the gauged catchment appears to be acting as a pervious surface and hence although runoff may occur frequently, the quantity of this runoff will be small.

\subsection{Runoff Quality}

As mentioned previously, recent studies have found runoff from permeable pavements to have lower contamination levels than runoff from impervious road surfaces. A total of 9 events were sampled during the monitoring period. Shown in Table 2 is a summary of the EMC values obtained for the sampled events; the range and the median values are shown.

Insert Table 2

To assess whether this was the case at Smith Street, typical values for the concentration of major road runoff pollutants have been collated. Hogan (2000) reports on heavy metal concentrations in runoff from a site at Mascot, Sydney. Drapper (2000) similarly reportsen heavy metal contamination of road runoff, but in South-east Queensland. Drapper (200) as considered the phosphorous loads in road runoff.

Provided in Table 3 is a summary of typical road runoff quality and a comparison with the monitoring results obtained at Smith Street. Median values are reported rather than average, as these values are not influenced to the same degree by outliers in the data (Drapper, 2000). The only metal constituents compared in Table 2 are Copper, Lead and Zinc. These metals have been reported previously by Berbee et al. (1999) to be the prevailing trace metals in runoff from both pervious and impervious pavements. Ball (2000) similarly reports that studies undertaken in the Sydney suburbs of Kingsford and Allambie found loads of Copper, Lead and Zinc to be higher than other trace metals.

\section{Insert Table 3}

As seen in Table 3, the runoff from the permeable pavement in Smith Street is not significantly different to typical values of road runoff. Total phosphorous appears to have the best fit with the typical ranges reported by Drapper (2000) for South-east Queensland road runoff and by Barrett et al. (1993) whose studies were based in Texas. The range of EMC values found for Copper, Zinc and Lead in runoff from Smith Street are not significantly different to typical road runoff; however, as shown above, they are at 
the lower end of typical ranges. The EMC values obtained also are lower than the median values reported by Hogan (2000) for the Mascot field site in Sydney, and the median values reported by Drapper (2000) for roads in South East Queensland.

It is unclear from the analysis undertaken on the Smith Street data as to why the EMC values associated with heavy metals in runoff from Smith Street are mainly at the lower end of the typical range while those for phosphorous seem to be similar to the typical range. Various studies have found permeable pavements to be able to retain large portions of the heavy metal loads (Berbee et al., 1999, Dierkes et al., 1999 and Legret and Colandini, 1999). It is considered that this effect may have occurred in the Smith Street pavement. Another possibility is that the site may simply have lower heavy metal accumulation in comparison to other roads studied in Sydney and South-east Queensland due to the lower traffic volumes. However, research undertaken by Drapper et al. (1999) found that traffic volumes seem to have minimal influence on road runoff concentrations. Without further investigations of the pavement surface an explanation cannot be given.

A wide range of EMCs occurred during the monitoring period. This is due to factors such as variation in time between events allowing for different quantity of pollutant build-up, and also to be due to the variation in the quantity of rainfall, differences in the rainfall intensity, and different volumes of runoff occurring. To determine the contribution that the fint for pollutant build-up had on the water quality recorded in the Smith Street runoff, EMC values were plotted against time since the previous runoff event. While this will not provide a full indication of cleansing events (factors such as wind are not considered), it does provide an indication of the impact of pollutant build-up on the runoff quality.

Plots developed for Copper, Lead, Zinc, and Phosphorous are shown in Figure 9. As shown in the $\mathrm{R}^{2}$ values provided with these plots, some correlation was found between the time since the last runoff event and the EMC. However this correlation was not high. The correlation found with lead was particularly low. Similar plots were developed for the other metal constituents analysed in this study resulting in a similar level of correlation to that found for Phosphorous, Copper and Zinc.

\section{Insert Figure 9}

In summary, the quality of the runoff from Smith Street was found to be comparable to typical urban road runoff. Metal concentrations were at the lower end of the values used for the purposes of comparison which may indicate that the permeable pavement is producing some metal retention capabilities, however this has not been verified. It should be noted, however, that the load of pollutants in the runoff from the 
Smith Street pavement has been reduced. The catchment now appears to be acting as a pervious surface, indicating that the permeable pavement has reduced the quantity of runoff. Since pollutants on the catchment surface are primarily transported with the runoff, the reduction in the quantity of runoff implies a reduction in the total load of pollutants leaving the catchment.

\section{CONCLUSIONS}

The effectiveness of the permeable pavement constructed in Smith Street Manly has been assessed. This assessment has taken place through the monitoring of storm events at the site and subsequent analysis of the results obtained. It was found that the Smith Street catchment is acting effectively as a pervious surface. This was shown through the determination of runoff coefficients during the supply period for each runoff event recorded which ranged from $0.04 \%$ to $7.33 \%$ compared with a range of $5 \%$ to $35 \%$ being representative of pervious surfaces. Further to this, the effective imperviousness of the catchment seems to have been reduced from around $45 \%$ prior to the installation of the pavement to about $3 \%$. This suggests that the installation of the permeable pavement has been effective in restoring permeability to this urban catchment.

Both the quantity of rainfall and sudden initiation of runoff. Analysis of the data suggests that about $4 \mathrm{~mm}$ of rain is required before any runoff occurs. Furthermore, a rainfall intensity of about $20 \mathrm{~mm} / \mathrm{hr}$ is needed to produce runoff irrespective of the total depth of rainfall.

In relation to the quality of the runoff from Smith Street, it was found that the range of values found for the constituents monitored at the site was not significantly different to values typically found for urban road runoff. However, the EMC values for total phosphorous were closer to typical values than the heavy metals which were found to be at the lower end of the range of typical values.

Further to the issue of water quality from the Smith Street site, while the EMC values found in the runoff may not appear to show that the runoff quality from the permeable pavement surface is an improvement over a typical road surface, the total load of pollutants leaving the catchment has been reduced. The load of pollutants is directly related to the runoff flow rate. Since the quantity of runoff has been shown to have reduced, the total pollutant load leaving the catchment will similarly be reduced.

In summary, the permeable pavement in Smith Street was effective in reducing the quantity of runoff and hence in reducing the total load of pollutants leaving the catchment with stormwater runoff. 


\section{REFERENCES}

ASCE, (1969), Design and Construction of Sanitary and Storm Sewers, American Society of Civil Engineers, New York, NY, USA.

Baek, SO, Goldstone, ME, Kirk, PWW, Lester, JN, and Perry, R, (1991), Phase distribution and particle size dependency of polycyclic aromatic hydrocarbons in the urban atmosphere, Chemosphere, 22:503-520.

Ball, JE, (2000), Runoff from Road Surfaces: How Contaminated is it ?, Proceedings of the Hydrology and Water Resources Symposium, Perth, Australia, pp 259-264.

Ball, JE, and Abustan, I, (1995), An investigation of the particle size distribution during storm events on an urban catchment, Proceedings of the 2nd International Symposium on Urban Stormwater Management, IEAust, Melbourne, Australia, pp 531-535.

Ball, JE, Jenks, R, and Aubourg, D, (1998), An assessment of the availability of pollutant constituents on road surfaces, The Science of the Total Environment, 209:243-254.

Ball, JE and Scarsbrick, J, (2001), Keys to Open the Way Forward to Stormwater Sustainability, Proc. NSW Coastal Conference, Newcastle.

Barrett, ME, Irish, LB, Jr., Malina, JF, Jr., and Charbeneau, RJ, (1998), Characterization of Highway

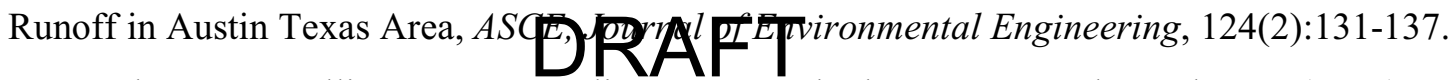

Barrett, ME, Zuber, RD, Collins, ER, III, Malina, JF, Jr., Charbeneau, RJ and Ward, GH, (1993), A review and evaluation of literature pertaining to the quantity and control of pollution from highway runoff and construction, Technical Report No CRWR 239, Centre for Research in Water Resources, University of Texas at Austin, Austin, TX, USA

Batley, GE, Brockbank, CI, Hogan, PM, and Ball, JE. (1994), The chemical composition of stormwater runoff from roads, Investigation Report CET/IR263, Centre for Analytical Chemistry, Division of Coal and Energy, CSIRO

Berbee, R, Gerard, R, de Brouwer, R, van Velzen, L, (1999), Characterization and Treatment of Runoff from Highways in the Netherlands Paved with Impervious and Pervious Asphalt, Water Environment Research, 71(2):183-190.

Bettess, R. (1996) Infiltration drainage - manual of good practice. Construction Industry Research and Information Association, Report 156, London.

Bradford, WL, (1977), Urban Stormwater Pollutant Loadings: A Statistical Summary through 1972, Journal of the Water Pollution Control Federation, 49:613-622.

Brockbank, CI, Batley, GE, Ball, JE and Tilley, JH, (1998), Metals and hydrocarbons in stormwater runoff from urban roads, Investigation Report ET/IR98, Division of Energy Technology, Centre for Advanced Analytical Chemistry, CSIRO. 
Dierkes, C, Holte, A, and Geiger, WF, (1999), Heavy Metal Retention within a Porous Pavement Structure, Proceedings of the 8th International Conference on Urban Storm Drainage, Sydney, Australia.

Dierkes, C, Kuhlmann, L, Kandasamy, JK and Angelis, G, (2002), Pollution Retention Capability and Maintenance of Permeable Pavements, Proc. $9^{\text {th }}$ International Conference on Urban Drainage, Portland, Oregon, USA, published as a CD.

Drapper, D, Tomlinson, R, and Williams, P, (1999), An Investigation of the Quality of Stormwater Runoff from Road Pavements; A South-East Queensland Case Study. Proceedings of the 8th International Conference on Urban Storm Drainage, Sydney, Australia.

Drapper, DW, (2000), Pilot Study of Pollutants in Road Runoff and Evaluation of Best Management Practices for South-east Queensland, Doctoral Dissertation, School of Environmental Engineering, Griffith University.

Ellis, JB and Revitt, DM, (1982), Incidence of heavy metals in street surface sediments: Solubility and grainsize studies, Water Air Soil Pollution, 17:87-100

Environment Australia, (2002), Introduction to Urban Stormwater Management in Australia, Commonwealth of Australia, Prepared Under the Urban Stormwater Initiative of the Living Cities Program 2002, ISBN 0642548323.

Hogan, PM, (2000), Modelling of Heavy MetalEntertainment and Transport from Road Surfaces by Rainfall Induced Stormwater Distharge, Doctoral Dissertation, School of Civil and Environmental Engineering, The University of New South Wales, Sydney, Australia.

Huber, WC, (1993), Contaminant Transport in Surface Water, Chapter 14, Maidment, DR, (Ed) Handbook of Hydrology, McGraw Hill, USA.

Hunt, B, Stevens, S, and Mayes, D, (2002), Permeable Pavement Use and Research at Two Sites in Eastern North Carolina, Proc. $9^{\text {th }}$ International Conference on Urban Drainage, Portland, Oregon, USA, published as a CD.

Institute of Engineers, Australia, (1987), Australian Rainfall and Runoff: A Guide to Flood Estimation, I.E. Aust., Canberra.

Jy, SW, Allan, CJ, Saunders, WL and Evett, JB, (1998), Characterization and Pollutant Loading Estimation for Highway Runoff, ASCE, Journal of Environmental Engineering, 124(7):582-594 Legret, M., and Colandini, V. (1999) Effects of a Porous Pavement with Reservoir Structure on Runoff Water: Water Quality and Fate of Heavy Metals, Water Science Technology, 39(2):111-117. NSW EPA, (1997), Managing Urban Stormwater: Treatment Techniques, NSW EPA, Sydney.

Pratt, CJ, Mantle, JDG and Schofield, PA, (1995), UK Research into the Performance of Permeable Pavement, Reservoir Structures in Controlling Stormwater Discharge Quantity and Quality, Water Science Technology, 32(1):63-69. 
Rocla, (2002), Project Bulletin : Smith St Manly - Ecoloc Pavement, Unpublished Bulletin, Rocla Pty Ltd.

Rushton, BT, (2001), Low-impact parking lot design reduces runoff and pollutant loads, ASCE, Journal of Water Resources Planning and Management,

Sansalone, JJ, (1996), Characterisation of solid and metal element distributions in urban highway stormwater, Proc 7th International Conference on Urban Storm Drainage, Hannover, Germany, pp $253-258$.

Sansalone, JJ and Buchberger, SG, (1995), An Infiltration Device as a Best Management Practice for Immobilizing Heavy Metals in Urban Highway Runoff, Water Science and Technology, 32(1):119-125.

Sartor, JD and Boyd, GB, (1972), Water Pollution Aspects of Street Surface Contaminants, Report No. EPA-R2-72/081, US Environmental Protection Agency, Washington, DC, USA.

Shaheen, DG, (1975), Contribution of urban roadway usage to water pollution, Report No. EPA-600/2-75/004, Municipal Pollution Control Division, Office of Research and Development, US Environmental Protection Agency, Washington DC, USA.

US EPA (1999), Stormwater Technology Fact Sheet: Porous Pavement, Report No. EPA-832-F-99-023, US EPA, Washington, DC, USA.

Walker, DJ, and Hurl, S, (2002), The reduction of heavy metals in a stormwater wetland, Ecological Engineering, 18:407-414. 


\section{LIST OF FIGURES}

Figure 1 - Location of Smith Street Catchment

Figure 2 - Gauged Catchment at Smith Street

Figure 3 - Rating Curve for Smith Street Gauging Station

Figure 4 - Comparison of Monthly Rainfall recorded with Average Monthly Rainfall at Observatory Hill, Sydney

Figure 5 - Recorded Maximum 5 Minute Rainfall Intensities For Each Event

Figure 6 - Imperviousness of the Gauged Smith Street Subcatchment

Figure 7 - Estimation of the Effective Imperviousness

Figure 8 - Influence of Rainfall Intensity on Runoff Depth

Figure 9 - a) Exceedance Probability for EMC of Copper

Figure 9 - b) Exceedance Probability for EMC of Lead

Figure 9 - c) Exceedance Probability for EMC of Zinc

Figure 9 - d) Exceedance Probability for EMC of Phosphorous

\section{LIQDRAPFES}

Table 1 - Typical Road Runoff Contaminants and Their Sources (after Ball et al., 1998)

Table 2 - Summary of Runoff Quality

Table 3 - Comparison of Road Runoff Quality 


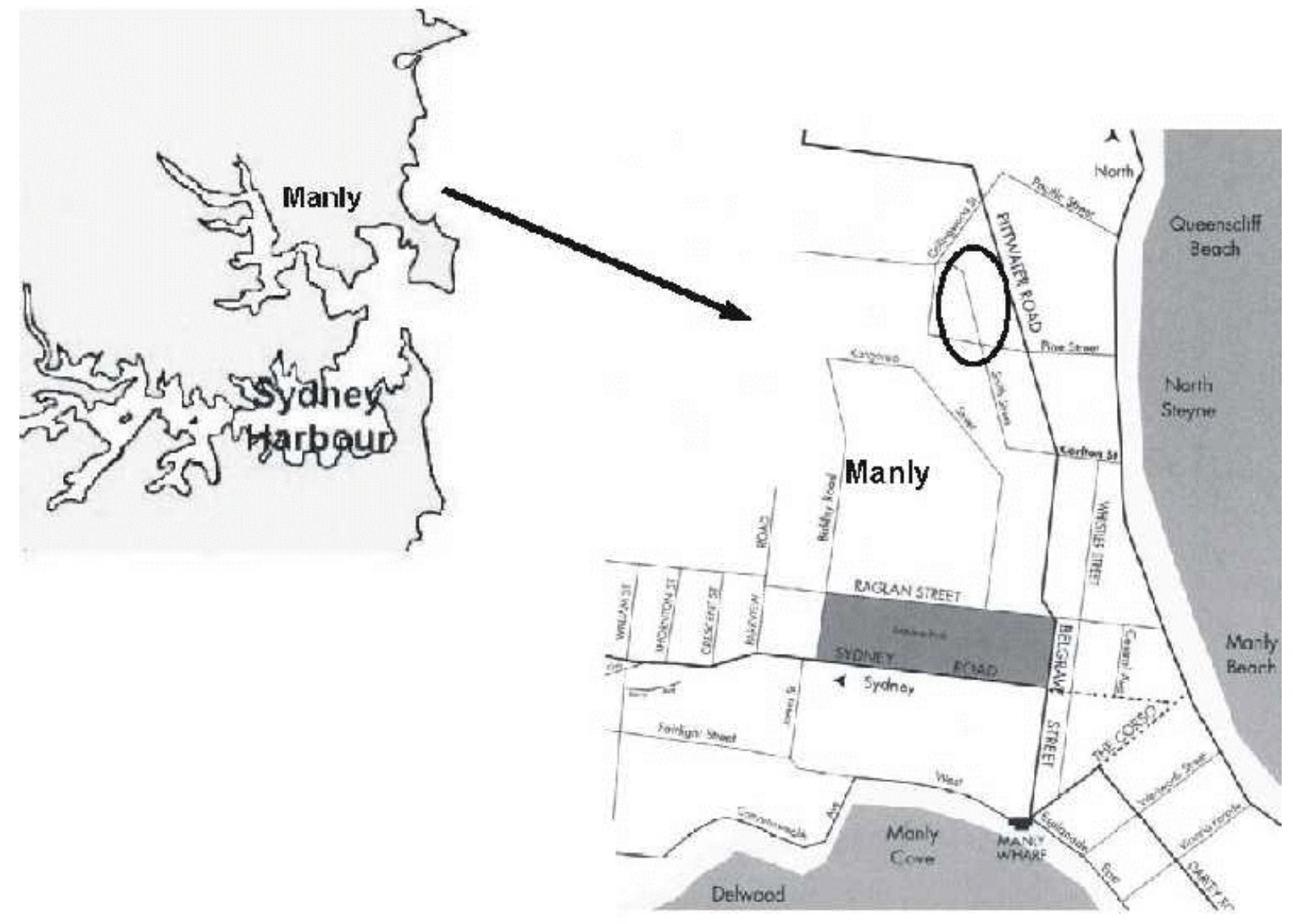

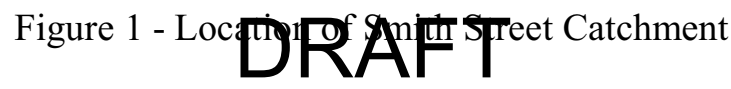




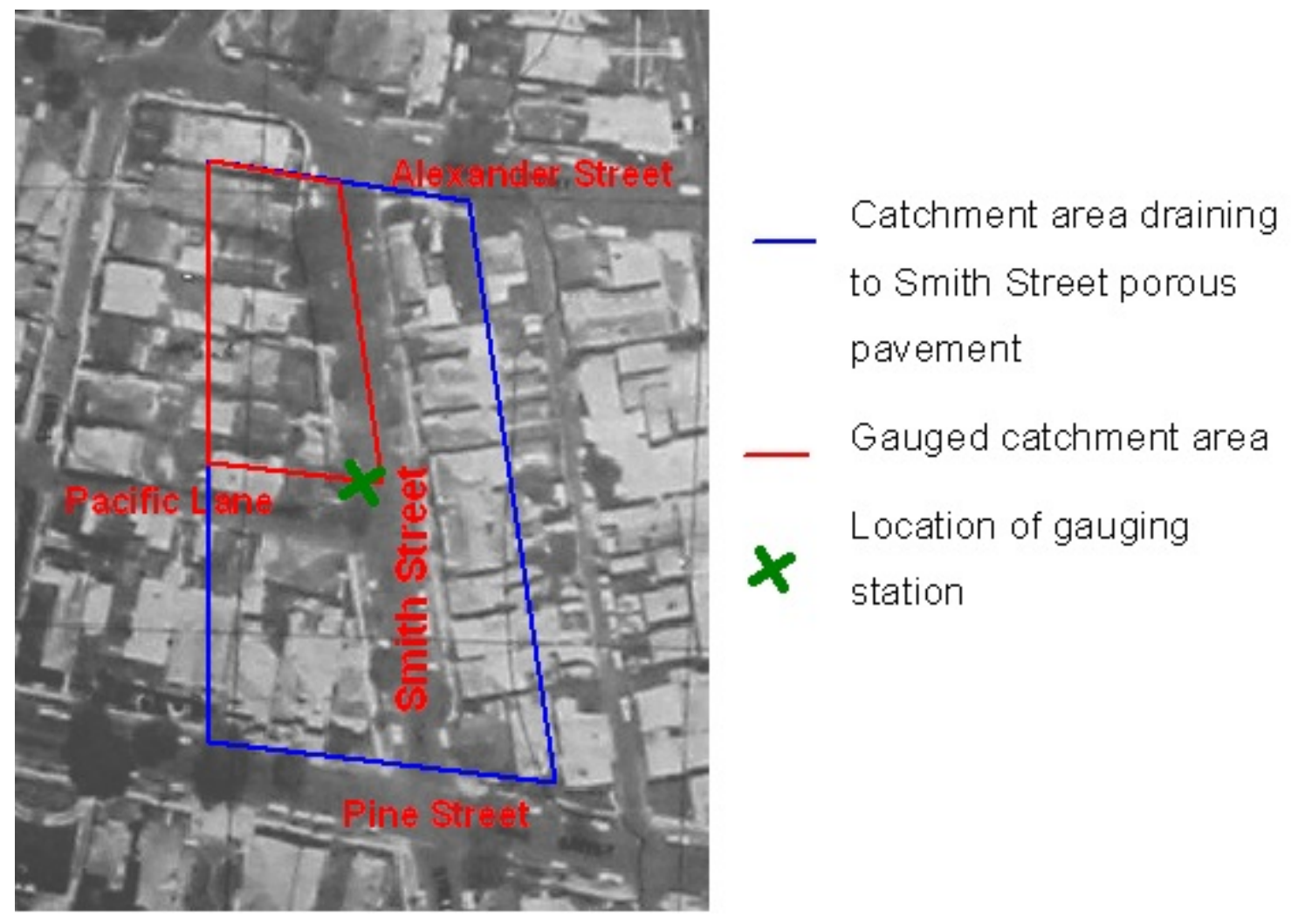

Figure 2 - Gauged Catchment at Smith Street

\section{DRAFT}




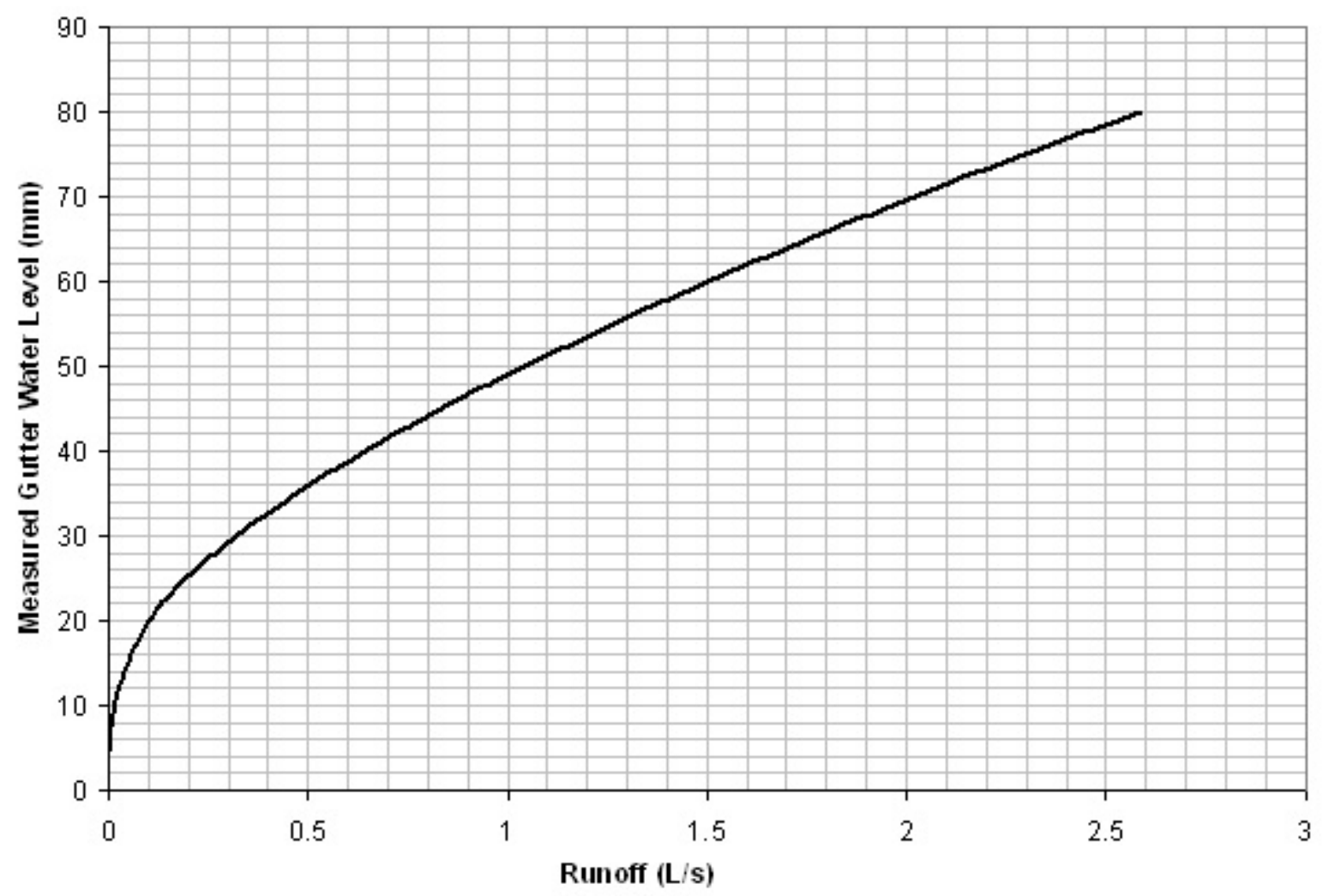

Figure 3 - Rating Curve for Smith Street Gauging Station

\section{DRAFT}




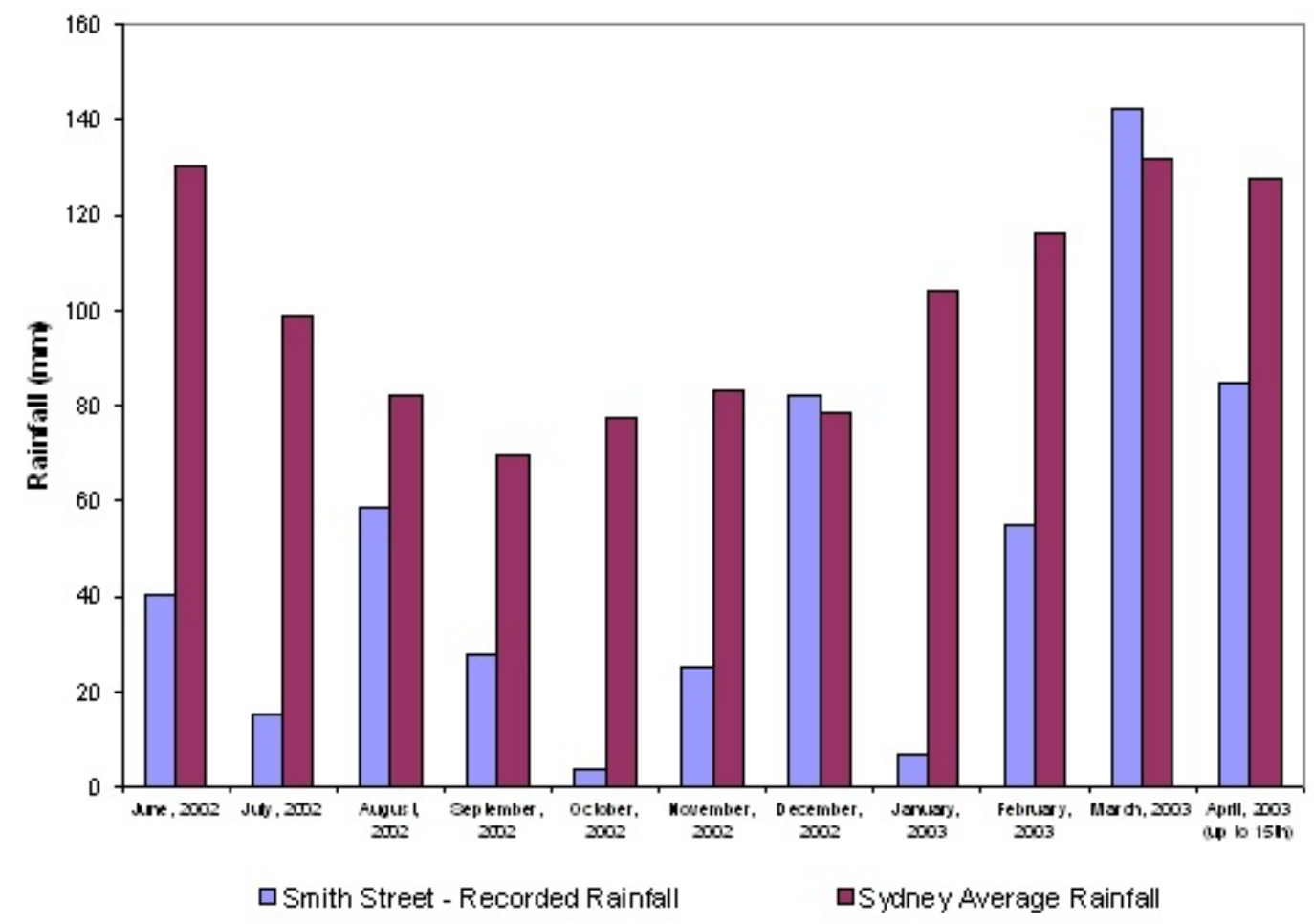

Figure 4 - Comparison of Monthly Rainfall recorded with Average Monthly Rainfall at Observatory Hill, Sydney

\section{DRAFT}




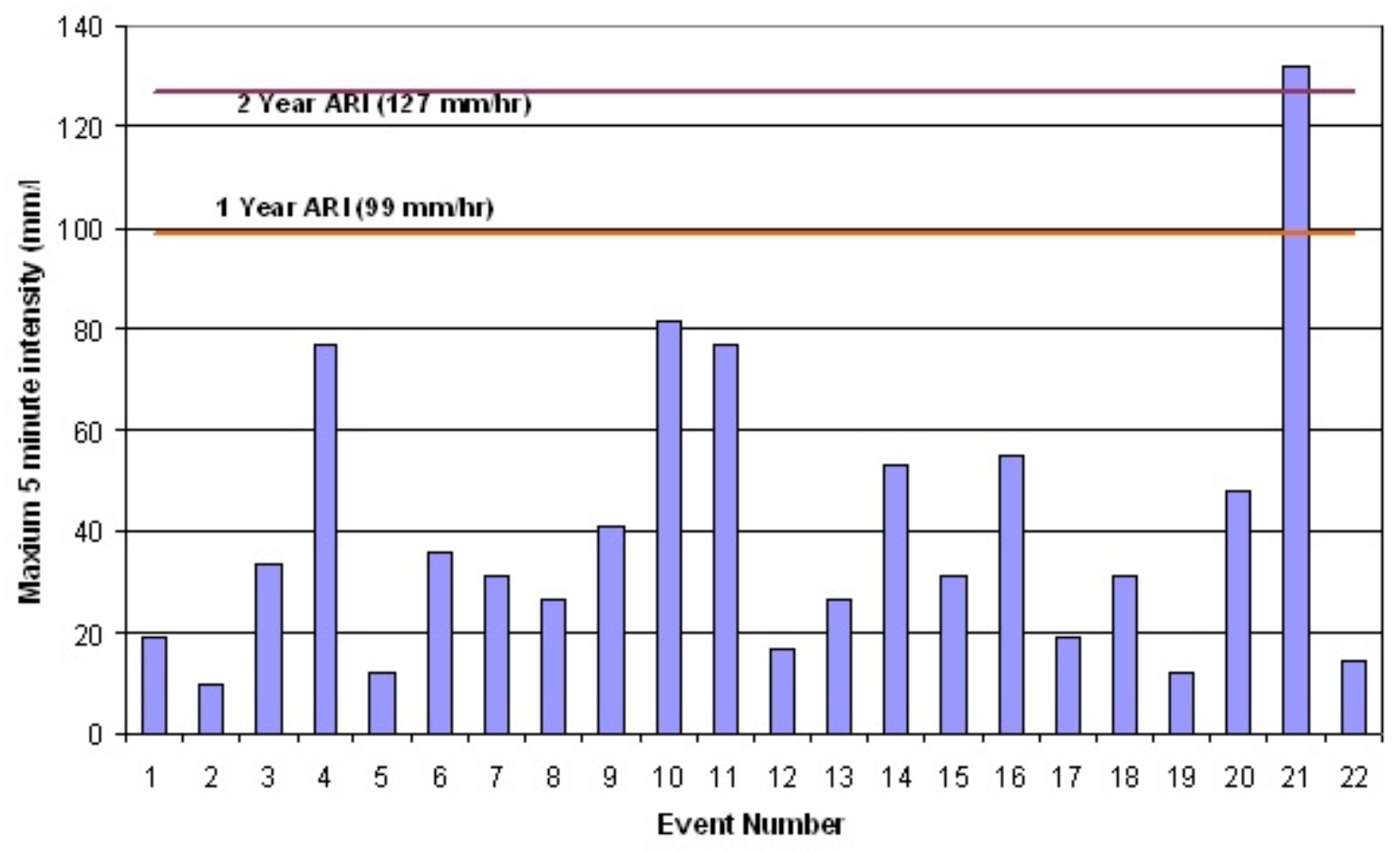

Figure 5 - Recorded Maximum 5 Minute Rainfall Intensities For Each Event

\section{DRAFT}




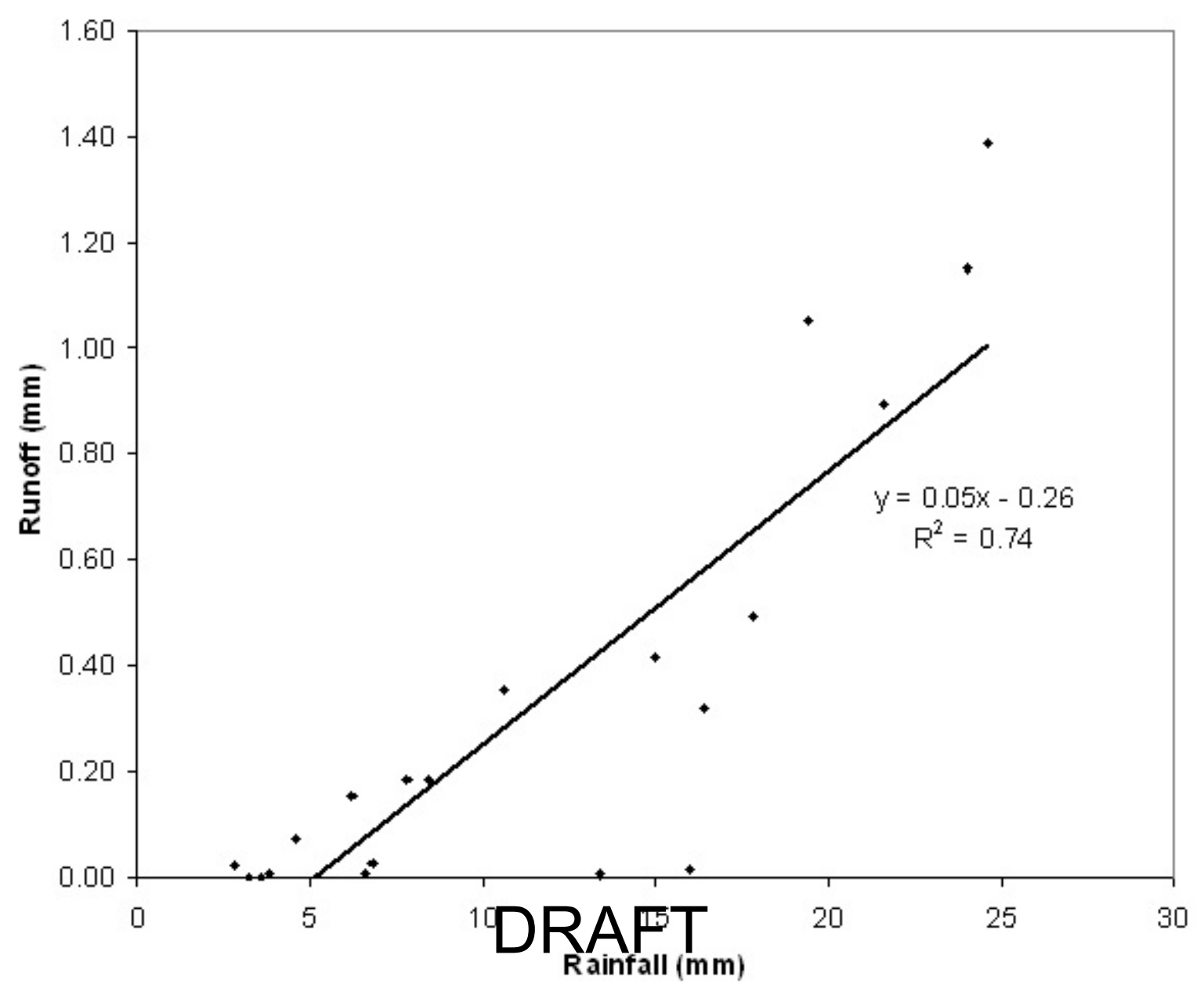

Figure 6 - Imperviousness of the Gauged Smith Street Subcatchment 


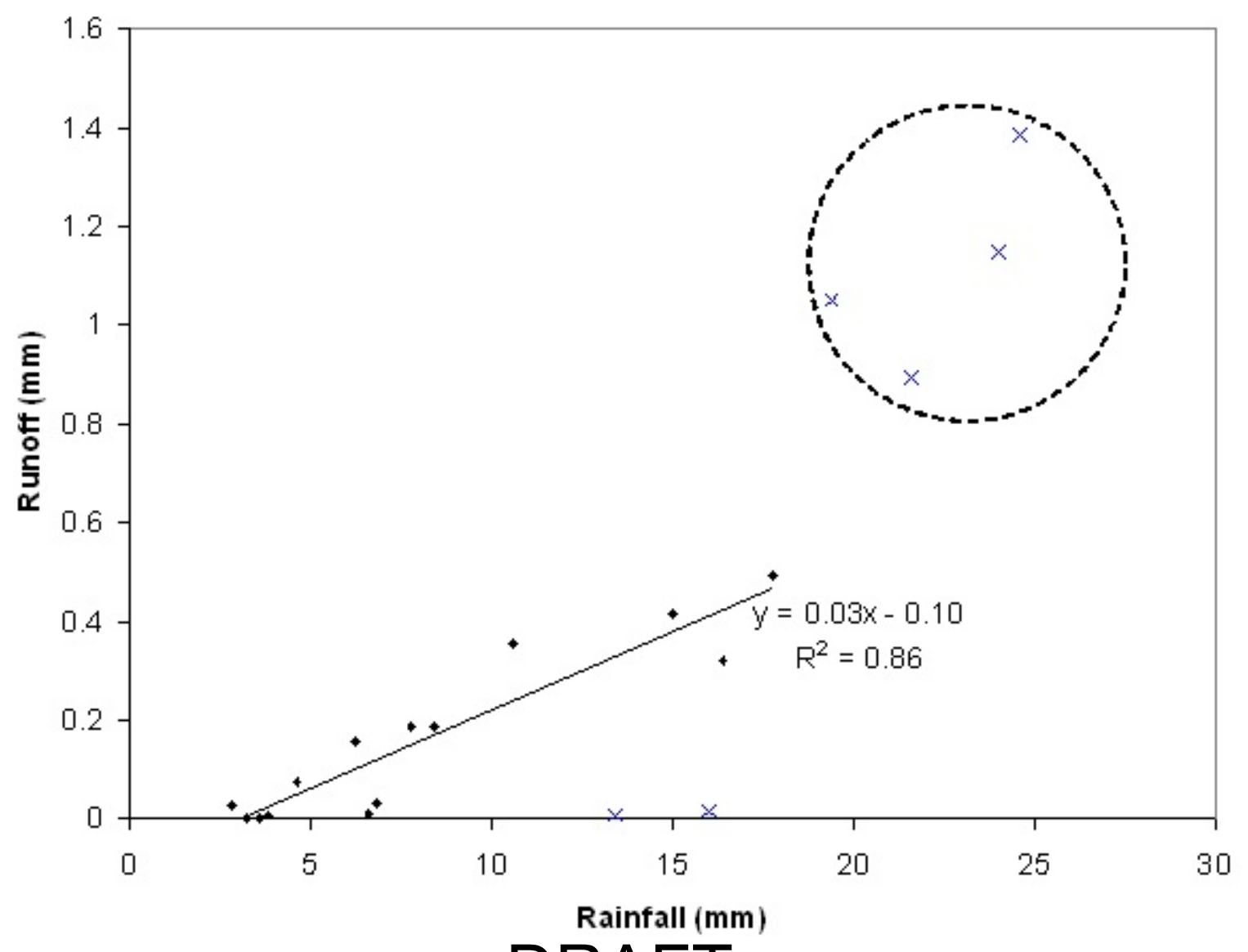

Figure 7 - Estimat of Afective Imperviousness 


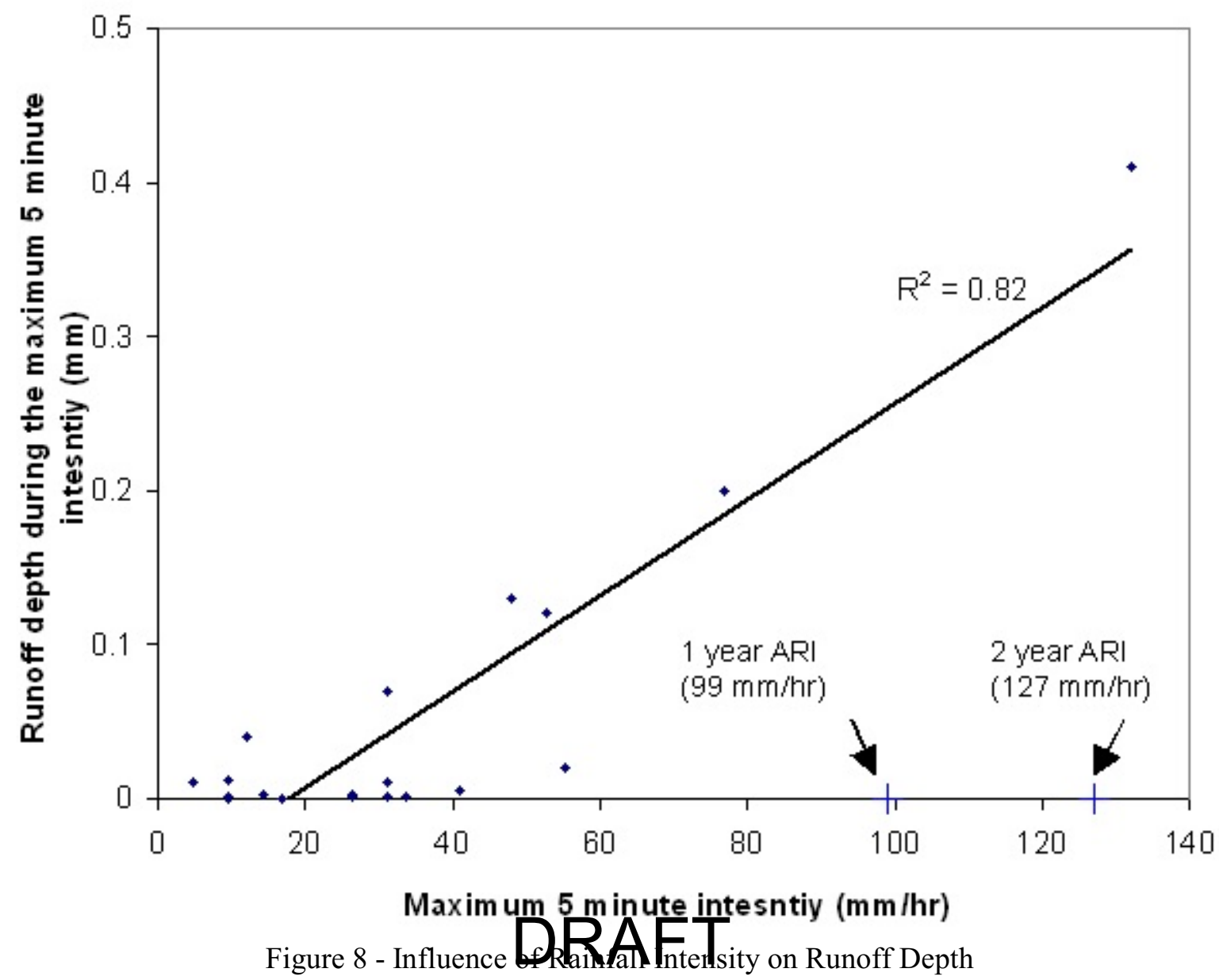




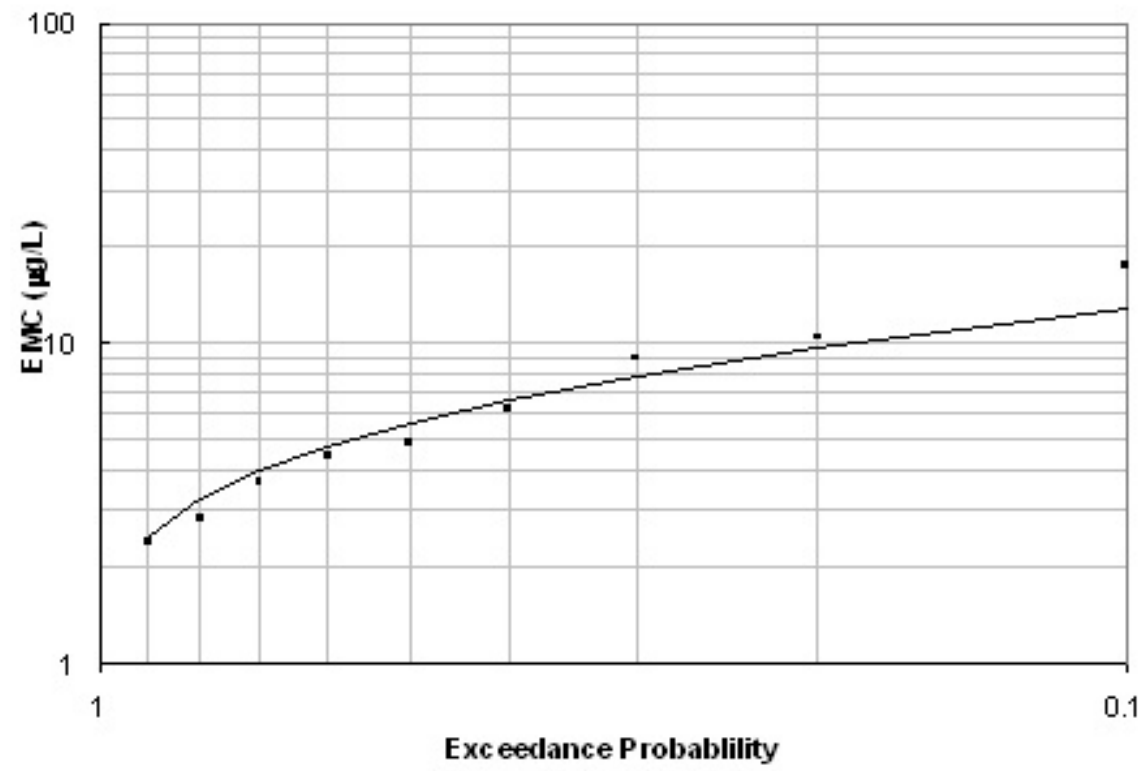

Figure 9 - a) Exceedance Probability for EMC of Copper

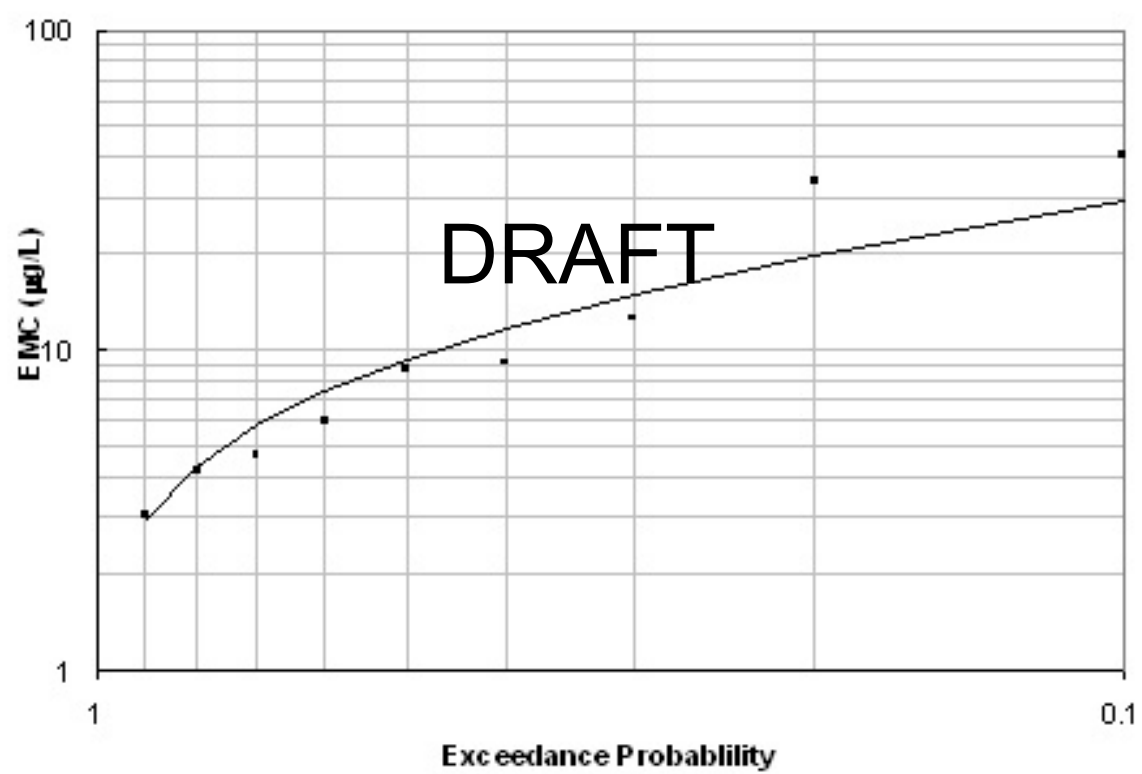

Figure 9 - b) Exceedance Probability for EMC of Lead 


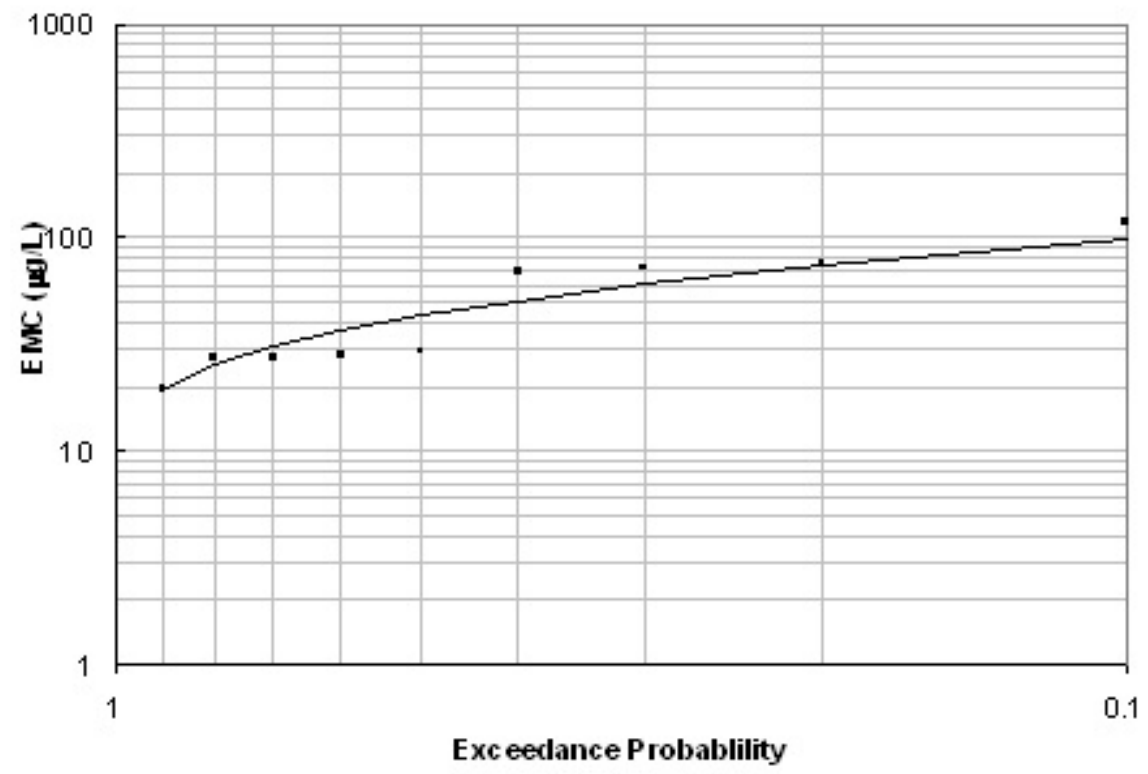

Figure 9 - c) Exceedance Probability for EMC of Zinc

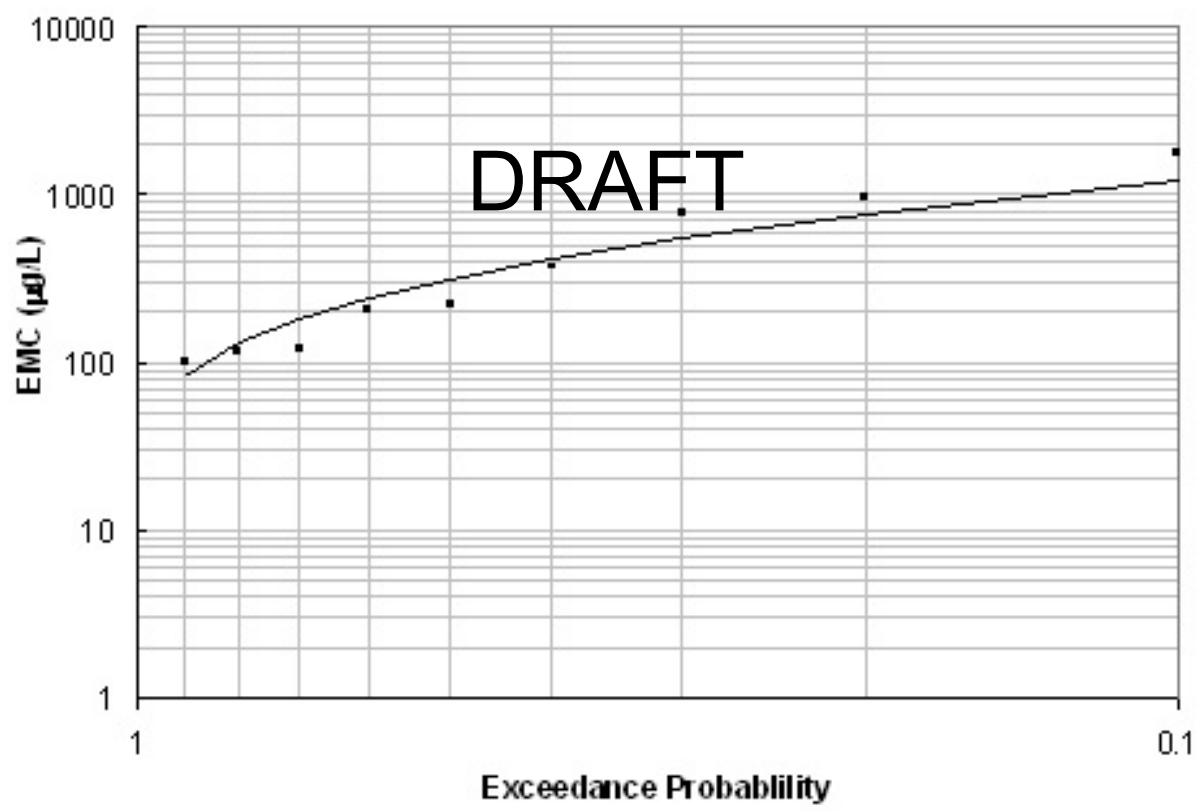

Figure 9 - d) Exceedance Probability for EMC of Phosphorous 
Table 1 - Typical Road Runoff Contaminants and Their Sources (after Ball et al., 1998)

\begin{tabular}{|c|c|}
\hline Contaminant & Primary Source \\
\hline Sediment & $\begin{array}{l}\text { Pavement wear, vehicles, maintenance } \\
\text { activities }\end{array}$ \\
\hline Nitrogen & Roadside fertiliser applications \\
\hline Phosphorous & Roadside fertiliser applications \\
\hline Lead & $\begin{array}{l}\text { Auto exhaust, tyre wear, lubricating oil and } \\
\text { grease, bearing wear }\end{array}$ \\
\hline Zinc & Tyre wear, motor oil, grease \\
\hline Iron & $\begin{array}{l}\text { Auto rust, steel highway structures (eg guard } \\
\text { rails), moving engine parts }\end{array}$ \\
\hline Copper & $\begin{array}{l}\text { Metal plating, bearing and brush wear, } \\
\text { moving engine parts, brake lining wear, } \\
\text { fungicides, insecticides, pesticides }\end{array}$ \\
\hline Cadmium & Tyre wear, insecticide application \\
\hline Chromium & Metal plating, moving parts, brake lining wear \\
\hline Nickel & $\begin{array}{l}\text { Diesel fuel and petrol exhaust, lubricating oil, } \\
\text { metal plating, brush wear, brake lining wear, } \\
\text { asphalt paving }\end{array}$ \\
\hline Manganese & Moving engine parts, auto exhaust \\
\hline Cyanide & \\
\hline $\begin{array}{l}\text { Sodium/Calcium } \\
\text { Chloride }\end{array}$ & Deicing salts \\
\hline Sulfate & Roadways surfaces, fuels, deicing salts \\
\hline $\begin{array}{l}\text { Petroleum } \\
\text { Hydrocarbons }\end{array}$ & $\begin{array}{l}\text { Spills, leaks, or blow-by of motor lubricants, } \\
\text { anti-freeze and hydraulic fluids, asphalt } \\
\text { surface leachate }\end{array}$ \\
\hline PCB & $\begin{array}{l}\text { PCB catalyst in synthetic tyres, spraying of } \\
\text { rights-of-way }\end{array}$ \\
\hline PAH & asphalt surface leachate \\
\hline
\end{tabular}


Table 2 - Summary of Runoff Quality

\begin{tabular}{c|c|c} 
Constituent & $\begin{array}{c}\text { EMC Range } \\
(\mu \mathrm{g} / \mathrm{L})\end{array}$ & $\begin{array}{c}\text { Median EMC } \\
(\mu \mathrm{g} / \mathrm{L})\end{array}$ \\
\hline Iron & $30.80-780.09$ & 158.26 \\
Cadmium & $0.31-1.21$ & 0.51 \\
Chromium & $0.31-1.61$ & 0.60 \\
Copper & $2.39-17.58$ & 4.87 \\
Manganese & $1.72-51.68$ & 11.76 \\
Nickel & $0.31-1.79$ & 0.62 \\
Lead & $3.08-40.58$ & 8.79 \\
Zinc & $19.55-119.26$ & 29.35 \\
Phosphorous & $101.56-1796.69$ & 222.21 \\
Suspended Solids $(\mathrm{mg} / \mathrm{L})$ & $8.09-76.66$ & 22.59 \\
$\mathrm{pH}$ & $6.3-6.7$ & - \\
Conductivity $(\mu \mathrm{S} / \mathrm{cm})$ & $29-233$ & -
\end{tabular}

\section{DRAFT}


Table 3 - Comparison of Road Runoff Quality

\begin{tabular}{|c|c|c|c|c|c|}
\hline Constituent & $\begin{array}{c}\text { Smith Street } \\
\text { EMC Range } \\
(\mu \mathrm{g} / \mathrm{L})\end{array}$ & $\begin{array}{l}\text { Smith Street } \\
\text { Median EMC } \\
(\mu \mathrm{g} / \mathrm{L})\end{array}$ & $\begin{array}{c}\text { Typical Road } \\
\text { Runoff Median } \\
\text { EMC }(\mu \mathrm{g} / \mathrm{L})^{a}\end{array}$ & $\begin{array}{c}\text { Road } \\
\text { Runoff at } \\
\text { Mascot } \\
(\mu \mathrm{g} / \mathrm{L})^{b} \\
\end{array}$ & $\begin{array}{c}\text { Road Runoff } \\
\text { South-east } \\
\text { Queensland } \\
(\mu \mathrm{g} / \mathrm{L})^{c} \\
\end{array}$ \\
\hline $\begin{array}{c}\text { Total } \\
\text { Phosphorous }\end{array}$ & $102-1800$ & 222 & & - & $190-2000$ \\
\hline Copper & $2-18$ & 5 & $\begin{array}{c}\text { A: } 41-155 \\
\text { B: } 7-37 \\
\text { C: } 2.5-15 \\
\text { D: } 6-49\end{array}$ & 40.7 & $30-280$ \\
\hline Zinc & $19-120$ & 29 & $\begin{array}{c}\text { A: } 172-2892 \\
\text { B: } 24-222\end{array}$ & 60.5 & $160-1450$ \\
\hline Lead & $3-40$ & 9 & $\begin{array}{c}\text { A: } 173-1457 \\
\text { B: } 3-53 \\
\text { C: } 6-15 \\
\text { D: } 16-123\end{array}$ & 77.3 & $50-450$ \\
\hline $\mathrm{pH}$ & $6.3-6.7$ & - & $7.1-7.2^{*}$ & - & $5.95-6.76$ \\
\hline $\begin{array}{l}\text { Conductivity } \\
(\mu \mathrm{S} / \mathrm{cm})\end{array}$ & $29-233$ & - & - & - & $53-317$ \\
\hline $\begin{array}{c}\text { Suspended } \\
\text { Solids (mg/L) }\end{array}$ & $8-77$ & & {$\left[-798^{*}\right.$} & - & $60-1825$ \\
\hline
\end{tabular}

a) After Hogan (2000) $\left\{^{*}=\right.$ summary of a range of average values, after Barrett et al, (1993), A = Sansalone and Buchberger (1995), B = Barrett et al., (1998), C =Jy et al., (1998), D = Texas data after Irish et al., (1995) cited by Jy et al., (1998)\}

b) After Hogan (2000) - Total median values for Mascot Field Station. Note that these are median values and are not EMC values

c) After Drapper (2000) - range of median values for various sites in South East Queensland. Once again these are median values and not EMC values. 